\title{
PROTECTIVE EFFECTS OF ZINC AS ANTIOXIDANT AGAINST THE GENOTOXIC POTENTIAL OF DELTAMETHRIN
}

\author{
IBRAHIM M.A. ${ }^{1 *}$, KHALAF A.A. ${ }^{2}$, GALAL M.K. ${ }^{1}$ AND OGALY H.A. ${ }^{1}$ \\ 1Department of Biochemistry and Chemistry of Nutrition, Faculty of Veterinary Medicine, Cairo University, Giza, Egypt. \\ 2Department of Forensic Medicine and Toxicology, Faculty of Veterinary Medicine, Cairo University, Giza, Egypt. \\ *Corresponding Author: Email- marwa199@yahoo.com
}

Received: February 01, 2014; Accepted: March 03, 2014

\begin{abstract}
-
Background: The objective of this study was to examine the deltamethrin (DM)-induced testicular oxidative damage and genotoxicity and the possible mechanism by which zinc protects against these alterations in rats.

Methods: Four study groups of ten male rats were formed and treated for 90 days as follows: (G1) controls; (G2) DM-treated rats; (G3) rats treated with DM and zinc and (G4) zinc-treated rats. After the treatment period, the animals were euthanized, and samples were collected for analysis of the total antioxidant capacity (TAC), nitiric oxide (NO) and mutation in TP53 and H-Ras genes.

Results: DM-treated group showed a significant decrease in TAC and increased level of NO as compared to control group. Moreover, Mutations in both in TP53 and H-Ras genes were also observed. Co-treatment with Zn partially improved the oxidative stress induced by DM and decreased the frequency of genetic mutations.
\end{abstract}

Conclusion: Zinc is proved to ameliorate the adverse effects implicated by the DM.

Keywords- Deltamethrin, oxidative stress, mutation, testes, zinc.

Citation: Ibrahim M.A., et al. (2014) Protective Effects of Zinc as Antioxidant Against the Genotoxic Potential of Deltamethrin. International Journal of Molecular Biology, ISSN: 0976-0482 \& E-ISSN: 0976-0490, Volume 5, Issue 1, pp.-092-096.

Copyright: Copyright@2014 Ibrahim M.A., et al. This is an open-access article distributed under the terms of the Creative Commons Attribution License, which permits unrestricted use, distribution and reproduction in any medium, provided the original author and source are credited.

\section{Introduction}

The increasing release of chemicals into the environment dictates attention to a better understanding of their toxicity in human. Many studies suggest that environmental contaminants disrupt male reproductive function [1]. Since pyrethroids have been documented in 1970s, their usage has been increasing to replace the organophosphorus insecticides for residential control [2]. Deltamethrin (DM) is an alpha-cyano type II pyrethroid that is worldwide used in pest control. It is considered as one of the most potent pyrethroids [3]. Although initially thought to be least toxic, a number of recent reports showed its toxicity in mammalian and non-mammalian species. Its toxicity depends on the vertebrate species, route of administration and substance in which the preparation was done. DM had various adverse effects in experimental animals including the reproductive toxicity and endocrine disruption [4]. Toxicity of DM is mediated by the reactive oxygen species (ROS) production [5]. Oda \& El -Maddawy [6] have reported that DM induced lipid peroxidation in testes of rats, decreased the antioxidant status [7] and induced oxidative stress and tissue damage $[8,9]$.

Moreover, DM had a tumor initiating potential in Swiss albino mice [10]. Mutation in some regulatory genes is critical in the development of neoplasia [11]. A number of lines of evidence support an interaction between TP53 and ras genes in the process of tumorigenesis [12].
TP53 is one of tumor suppressor genes, encodes a 53KDa nuclear phosphoprotein (p53), acting predominantly as a transcription factor, promoting cell cycle arrest [13]. Ras oncogenes also are involved in a wide range of human tumors. There are three closely related cellular RAS genes (K-ras, $\mathrm{H}$-ras and $\mathrm{N}$-ras) encode for a 21 $\mathrm{kDa}$ protein (p21). It has intrinsic GTPasic activity and acts as a regulator of intracellular function [14].

The natural antioxidants may be helpful in preventing or reducing the harmful effects of ROS [15]. Zinc is an antioxidant factor as well as a core constituent of free scavenging enzymes such as copper/ zinc superoxide dismutase (SOD) [16]. Zinc plays an important role in transcription factor function and DNA repair [17]. Dietary zinc is generally considered to reduce the risk of cancer [18]. Moreover, zinc is important for reproduction due to its essential role in germ cell development [19]. Zinc supplementation might offset the damaging effects in testes [20].

The present work aimed to evaluate the oxidative stress induced by DM and investigate the efficiency of zinc as an antioxidant against the adverse effects of the chronic DM exposure on rat testes.

\section{Material and Methods \\ Animals}

Fourty male albino rats, weighing 150-170 g, were obtained from the breeding unit of Toxicology and forensic Medicine department, 
Faculty of Veterinary Medicine, Cairo University, and maintained under standard conditions (temperature $25 \pm 1^{\circ} \mathrm{C}$, humidity $55 \pm$ $5 \%$ and lights on from 06:00 to 18:00 h) with free access to food and water in accordance with the Ethical Principles for the Care and Use of Laboratory Animals [21].

Rats were randomly divided into four equal groups each consisting 10 rats:

The animals were grouped as follows:

\begin{tabular}{|c|c|c|c|}
\hline Groups & Treatment* & Dose & Period \\
\hline Group-I Control & Corn oil & Weight based & \\
\hline Group-II DM-treated & Deltamethrin & $0.6 \mathrm{mg} / \mathrm{kg} / \mathrm{day}$ & \\
\hline Group-III & 1st: Zn sulfate & $200 \mathrm{mg} / \mathrm{kg} / \mathrm{day}$ & morntur \\
\hline$(\mathrm{DM}+\mathrm{Zn}$ treated $)$ & 2nd: Deltamethrin (30 min later per) & $0.6 \mathrm{mg} / \mathrm{kg} / \mathrm{day}$ & \\
\hline Group-IV (Zn-treated) & Zn sulfate & $200 \mathrm{mg} / \mathrm{kg} / \mathrm{day}$ & \\
\hline \multicolumn{4}{|l|}{ *Treatment: } \\
\hline \multicolumn{4}{|c|}{ - All doses were given via stomach tube once daily for three months. } \\
\hline \multicolumn{4}{|c|}{$\begin{array}{l}\text { - Deltamethrin was prepared by dissolving in corn oil. While Zn sulpfate was dis- } \\
\text { solved in distilled water. }\end{array}$} \\
\hline
\end{tabular}

Deltamethrin ( $>99 \%$ pure) was obtained from $\mathrm{KZ}$ pesticide company (Egypt) and zinc sulfate was purchased from Sigma Chemical Co., USA.

The selected dose of DM was based on previous studies in which $1 / 10$ LD50 ( $0.6 \mathrm{mg} / \mathrm{kg}$ body weight) induced biochemical alteration in rat without morbidity [6], while that of $\mathrm{Zn}$ was added according to previous report [22].

\section{Sampling}

At the end of experiment, the animals were sacrificed by decapitation under ether anesthesia, the testes were removed and washed in physiological saline and divided into two portions: one for biochemical analysis and the other for genomic DNA extraction. Samples were immediately stored at $-20^{\circ} \mathrm{C}$.

\section{Biochemical Analysis}

Testes samples were homogenized in $0.1 \mathrm{M}$ phosphate buffer $(\mathrm{pH}$ 7.4) using Teflon pestle. The homogenates were centrifuged at $14,000 \mathrm{xg}$ for $15 \mathrm{~min}$ at $4^{\circ} \mathrm{C}$. The supernatant was stored at $-20^{\circ} \mathrm{C}$ until the TAC and NO were measured.

\section{Determination of Testicular TAC Level}

The TAC was measured colorimetrically according to Koracevic, et al [23] using kit supplied by Biodiagnostic, Egypt.

\section{Determination of Testicular NO Level}

NO level was assessed indirectly by measuring the nitrite level based on the modified method of Griess assay, described by Miranda, et al [24]. Briefly, the tissue homogenate was deproteinized with $30 \%$ zinc sulphate then tissue nitrate was reduced to nitrite by vanadium (III) chloride. Total nitrite, an indicator of NO, was then determined colorimetrically using Griess reagent by developing a purple color measured at $540 \mathrm{~nm}$.

\section{Genomic DNA Extraction}

Genomic DNA was extracted from testicular tissue using DNeasy Blood and Tissue Kit (Qiagen $\mathrm{GmbH}$; Hilden, Germany). DNA quality and quantity were estimated at $260 \mathrm{~nm}$ and $280 \mathrm{~nm}$ using a UNICAM spectrophotometer.

\section{Mutation Analysis of TP53 and H-RAS Genes Polymerase Chain Reaction (PCR)}

PCR amplification of the target TP53 and H-Ras gene sequences was carried out in $25 \mu$ reactions containing $0.25 \mathrm{U}$ Taq Polymerase, $2.5 \mu$ 10X PCR reaction buffer, $1 \mathrm{mM} \mathrm{MgCl} 2,2 \mathrm{mM}$ of each dNTP, (Jena Bioscience, Germany), about $100 \mathrm{ng}$ of extracted DNA as template and $10 \mathrm{pmol}$ of each specific primer [Table-1]. The thermal profile consisted of $5 \mathrm{~min}$ at $95^{\circ} \mathrm{C}, 35$ cycles of $94^{\circ} \mathrm{C}$ for 1 $\min , 59^{\circ} \mathrm{C}$ for $1 \mathrm{~min}$ and $72^{\circ} \mathrm{C}$ for $1 \mathrm{~min}$, with a final extension of 10 min at $72^{\circ} \mathrm{C}$. Obtained products were electrophoresed through $2 \%$ agarose gel with ethidium bromide.

\section{Single Strand Conformation Polymorphism (SSCP)}

For SSCP analysis, aliquot of each PCR product $(6 \mathrm{ml})$ was mixed with equal volume of denaturing buffer (Bromophenol Blue 0.025\% / Xylene Cyanole $0.025 \%$ / Formamide $98 \%$ ). The mixture was heated at $98^{\circ} \mathrm{C}$ for 10 minutes, and immediately chilled on ice for 10 min. The total volume was applied to a $15 \%$ polyacrylamide gel in 1x TBE buffer (Tris $100 \mathrm{mM}$, Boric Acid 9mM, EDTA 1mM) and electophoresed at 100V [27]. Gels were stained with ethidium bromide for 2 min and then destained by washing in deionized water. Gels were visualized under a UV transilluminator and photographed using a digital camera.

Table 1- Primers Used for TP53 and H-Ras Mutation Analysis

\begin{tabular}{|c|c|c|c|c|c|}
\hline Gene & Location & Direction & Primer sequence & Product Size & Reference \\
\hline \multirow{2}{*}{ TP53 } & \multirow{2}{*}{ Exon 7} & Forword & GTG GTA CCG TAT GAG CCA CC & \multirow{2}{*}{$157 \mathrm{bp}$} & \multirow{2}{*}{ [25] } \\
\hline & & Reverse & САA CCT GGC ACA CAG CTT CC & & \\
\hline \multirow{2}{*}{ H-RAS } & \multirow{2}{*}{ Exon 11} & Forword & GGAGACCCTGTAGGAGGACCC & \multirow{2}{*}{$72 \mathrm{bp}$} & \multirow{2}{*}{ [26] } \\
\hline & & Reverse & TCTATAGTGGGGTCGTATTCGTCC & & \\
\hline
\end{tabular}

\section{Statistical Analysis}

The obtained data were reported as means \pm standard error of means (SEM). Assessment of the results was performed using oneway analysis of variance (ANOVA). Fisher's exact test used to calculate the probability of the mutation frequency for both the studied genes. Statistical analysis was performed using SPSS 16.0 software package (SPSS Inc., Chicago, IL, USA). The 0.05 level of probability was used as criterion for significance.

\section{Results}

PCR-SSCP analysis of TP53 exon 7 on a 15\% PAGE showed a relevant alteration in bands mobility. The band pattern reveals the mutation exists in group (II) and (III) with the presence of an additional band. $\mathrm{C}=$ control group, $\mathrm{D}=\mathrm{DM}$ group (II), DZ= DM+ Zn group (III) and Z= zinc group (IV).

PCR-SSCP analysis of H-RAS exon 11 showed a relevant alteration in bands mobility on a $15 \%$ PAGE. The band pattern reveals 
whether a mutation exists in group (II) and (III) with decreasing in bands number while group (I) and (IV) had no mutation. C= control group, D= DM group (II), DZ= DM+ ZN group (III) and Z= zinc group (IV).
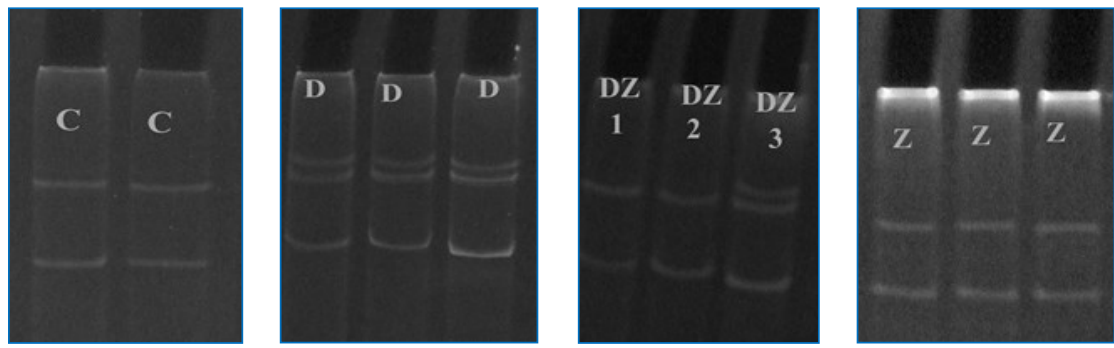

Fig. 1- Effect of deltamethrin and zinc on TP53 gene mutation in testicular tissue of rats.
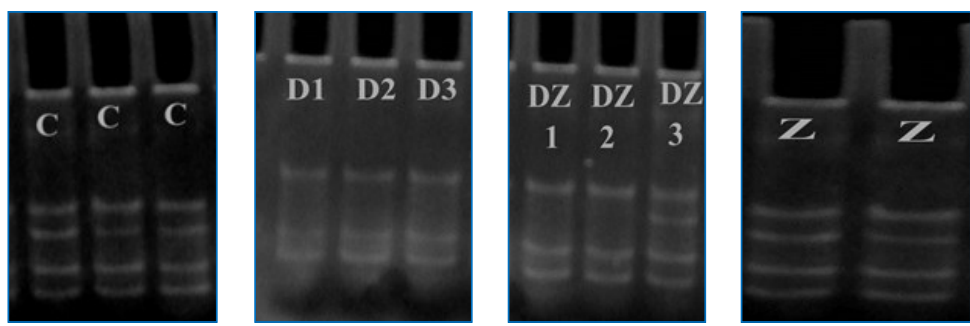

Fig. 2- Effect of deltamethrin and zinc on H-RAS gene mutation rat's testicular tissue.

Table 2- Effect of deltamethrin and zinc on testicular TAC and NO concentration in rats.

\begin{tabular}{|lccccc|}
\hline Parameters & Group (I) & Group (II) & Group (III) & Group (IV) & P value \\
\hline TAC (mmol/L) & $0.395 \pm 0.08$ & $0.202 \pm 0.10^{\mathrm{A}}$ & $0.235 \pm 0.07^{\mathrm{A}}$ & $0.251 \pm 0.06^{\mathrm{A}}$ & $0.00^{* \star \star}$ \\
NO $(\mu \mathrm{mole} / \mathrm{L})$ & $2.28 \pm 0.1$ & $8.44 \pm 1.01^{\mathrm{A}}$ & $2.92 \pm 1.00^{\mathrm{NS}}$ & $0.977 \pm 0.06^{\mathrm{A}}$ & $0.00^{* \star \star}$ \\
\hline
\end{tabular}

${ }^{* *}$ Significant effect within groups.

$A=$ Significant difference of every group to the control one at $p<0.05$ NS $=$ not significant .

Table 3- The frequency of TP53 mutation after DM intoxication and the protective effect of zinc in rat's testis.

\begin{tabular}{|lcccccccccc|} 
Duration of & \multicolumn{2}{c}{ Group (I) } & \multicolumn{2}{c|}{ Group (II) } & \multicolumn{2}{c|}{ Group (III) } & \multicolumn{2}{c|}{ Group (IV) } & P value \\
Exposure & $\mathbf{N}$ & $\%(\mathrm{M})$ & $\mathrm{N}$ & $\%$ (M) & $\mathbf{N}$ & $\%(\mathrm{M})$ & $\mathbf{N}$ & $\%(\mathrm{M})$ & \\
\hline 3 months & 10 & 0 & 10 & 100 & 10 & 50 & 10 & 0 & $0.0053^{*}$ \\
\hline
\end{tabular}

$M=$ mutant $\%, N=$ total number of rats

Table 4- The frequency of H-RAS gene mutation after DM intoxication and the protective effect of zinc in rat's testis.

\begin{tabular}{|c|c|c|c|c|c|c|c|c|c|}
\hline \multirow{2}{*}{$\begin{array}{l}\text { Duration of } \\
\text { Exposure }\end{array}$} & \multicolumn{2}{|c|}{ Group (I) } & \multicolumn{2}{|c|}{ Group (II) } & \multicolumn{2}{|c|}{ Group (III) } & \multicolumn{2}{|c|}{ Group (IV) } & \multirow[b]{2}{*}{ vaico } \\
\hline & $\mathbf{N}$ & $\%(\mathbb{M}$ & $\mathbf{N}$ & $\%$ (A) & $\mathbf{N}$ & $\%(\mathrm{M}$ & $\mathbf{N}$ & $\%$ (M) & \\
\hline & & & 10 & 100 & 10 & 40 & 10 & 0 & \\
\hline
\end{tabular}

$M=$ mutant $\% N=$ total number of rats.

\section{Discussion}

With the extensive use of DM pesticide in agriculture and domestic life, it becomes important to clarify the effect of DM on the reproductive function and to understand the mechanism which contributes to its reproductive toxicity.

The present study was conducted to throw light not only on the oxidative damaging effect of DM but also on the genotoxic and mutagenic effect on testes of rats as a result of chronic intoxication with DM.

During the past few years, estimation of free radical generation and antioxidants defense has become an important aspect for investigation of the mammalian cell action against oxidative damage induced by pesticides.
The results obtained in the present study revealed that DM induced significant decrease in TAC [Table-2]. This finding came in accordance with previous studies which reported that DM significantly decreased the antioxidant defense $[9,15,28,29]$. Also DM intoxication caused significant increase in NO concentration [Table-2]. This result was agreed with [30-32]. Possible reasons for reduction of TAC and increases of NO might be the utilization antioxidant enzymes to challenge the prevailing oxidative stress under the influence of free radicals generated from DM and/or inhibition of enzyme synthesis by DM [28,33-35].

Minerals like $\mathrm{Mn}, \mathrm{Cu}$ and $\mathrm{Zn}$ are involved in governing successful reproductive process [36]. In our study we showed that, Zn countered the oxidative stress produced by DM. A significant increase in TAC and decreases in NO was observed in group III in comparing to group II. This result came in the same line with [37-39] in testicular tissue. The protective effect of $\mathrm{Zn}$ through its action on the free radical production was reported by several studies [40-42]. The TAC not directly affected by dietary $\mathrm{Zn}$ as observed in group IV [Table-2]. This observation quite agreed with Song, et al [43]. Although Zn may not regulate antioxidant defenses directly, several other mechanisms could be involved in its action: (1) It protects sulfhydryl groups in proteins from oxidation, (2) It prevents the deleterious free-radical reactions stimulated by iron and copper, (3) It is a component of metallothioneins that are part of classic antioxidant defenses [43-45,], (4) and finally, it is an essential component of Cu/Zn SOD [40].

Like the other insecticides, DM affects non target organisms in addition to target one. It causes genotoxic, immunotoxic and tumorogenic effects [35,46-48]. Genotoxicity of a compound usually expressed as its ability to induce DNA damage, which is often essential for mutagenesis and cancer transformation [49]. In the present study DM appears to induce mutation in TP53 and H-RAS genes [Fig-1], [Fig-2], [Table-3] and [Table-4] in all exposed rats. A number of studies demonstrated the mutagenic effect of DM on testicular tissue [29,50-52]. It increased the expression of p53 and decreased expression of Bcl-2 genes in brain [53]. DM displays 
hepatic, renal toxicity and DNA damages in puberscent female rats [48]. The possible mechanism of DM genotoxicity is either to its reaction with DNA or by the generation of ROS which caused DNA damage [54-56]. The higher level of NO produced through DM intoxication inhibits cellular respiration and triggers apoptosis causing DNA damage [30]. Such oxidative DNA damage, if not repaired before replication, eventually result in mutations and initiate carcinogenesis. Our study denoted that $\mathrm{Zn}$ administration have a negative effect on the percentage of mutation induced by $D M$ for both genes [Table-3] and [Table-4]. This protective effect of $\mathrm{Zn}$ against DM intoxication was reported by several studies [22,37-39]. Zinc seems to have a special significance in maintaining DNA integrity, by its interaction with some of the responsible proteins, including those of the cell cycle, apoptosis, transcription and DNA damage response and repair [57, 58] Also Zn may prevent apoptosis through inhibiting the $\mathrm{Ca} 2+/ \mathrm{Mg} 2+-$ dependant endonuclease [59]. Such actions of $\mathrm{Zn}$ can play an important role in anticancer therapy.

\section{Conclusion}

The testicular toxicity of DM is at least partially due to the exacerbation of oxidative stress and its mutagenic effect. Supplementary zinc had an important modulator/protector effect may be due to its antioxidant activity.

\section{Conflicts of Interest: None declared.}

\section{References}

[1] Figà-Talamanca I., Traina M.E. and Urbani E. (2001) Occupational Medicine, 51(3), 174-188.

[2] Tu H.T., Silvestre F., Bernard A., Douny C., Phuong N.T., Tao C.T. and Kestemont P. (2008) Aquaculture, 285(1), 244-248.

[3] Wolansky M.J., Gennings C. and Crofton K.M. (2006) Toxicological Sciences, 89(1), 271-277.

[4] Abdallah F.B., Slima A.B., Dammak I., Keskes-Ammar L. and Mallek Z. (2010) Andrologia, 42(3), 182-186.

[5] Manna S., Bhattacharyya D., Mandal T.K. and Das S. (2005) Indian Journal of Pharmacology, 37(3), 160

[6] Oda S.S. and El-Maddawy Z.K. (2012) Experimental and Toxicologic Pathology, 64(7), 813-819.

[7] Rehman H., Ali M., Atif F., Kaur M., Bhatia K. And Raisuddin S. (2006) Clin. Chim. Acta, 369, 61-65.

[8] Durackova Z. (2010) Physiol. Res., 59, 459-469.

[9] Sakr S.A and Al-Amoudi W.M. (2012) Journal of Applied Pharmaceutical Science, 02(05), 22-27.

[10]Shukla Y., Arora A. and Singh A. (2001) Toxicology, 163(1), 19.

[11]Stanley L.A. (1995) Toxicology, 96(3), 173-194.

[12]Ferbeyre G. (2002) Leukemia, 16, 1918-1926.

[13]Raycroft L., Wu H. and Lozano G. (1990) Science, 249(4972), 1049.

[14]Bokoch G.M. and Der C.J. (1993) Faseb. J., 7(9), 750-759.

[15]Youssef M.I. (2010) Food and Chemical Toxicology, 48(5), 1152-1159.

[16]Aitken R.J. and Roman S.D. (2008) Adv. Exp. Med. Biol., 636, 154-171.

[17]Ho E. (2004) The J. Nutritional Biochemistry, 15(10), 572-578.
[18]Grant W.B. (2008) Anticancer Research, 28(3B), 1955-1963.

[19]Bedwal R.S. and Bahuguna A. (1994) Experientia, 50, 626-640.

[20]Tuncer I., Sunar F., Toy H., Baltaci A.K. and Mogulkoc R. (2011) Bratisl. Lek. Listy., 112(8), 425-427.

[21] Institute of laboratory animal resources (1995) Committee on Guide for the care and use of laboratory animals, National Research Council, 83.

[22]El-Refaiy A.I. and Eissa I. (2012) Comunicata Scientiae, 3(3), 162-180.

[23]Koracevic D., Koracevic G., Djordjevic V., Andrejevic S. and Cosic V. (2001) J. Clin. Pathol., 54(5), 356-361.

[24]Miranda K.M, Espey M.G., Wink D.A. (2001) Nitric Oxide, 5(1), 62-71.

[25]Gouda E., Elbehairy A. and Ghoneim M. (2008) Z. Naturforsch., 63c, 857-863.

[26]Sakamoto A., Oda Y., Adachi T., Tamiya S., Matsuda S., Tanaka K. and Tsuneyoshi M. (2001) American Journal of Clinical Pathology, 115(2), 235-242.

[27]Castelli E.C., Otake A.H. and de Oliveira D.E. (2002) J. Bras. Pathol. Med. Lab., 38, 75-82.

[28]Yalın S., Çömelekoğlu Ü., Mazmancı B., Ballı E., Eroğlu P., Sögüt F. and Ünyayar A. (2012) Turkish Journal of Biochemistry/Turk Biyokimya Dergisi, 37(4), 239-244.

[29]Slima A.B., Ali M.B., Barkallah M., Traore A.I., Boudawara T., Allouche N. and Gdoura R. (2013) Lipids in Health and Disease, 12(1), 30.

[30]El-Gohary M., Awara W.M., Nassar S. and Hawas S. (1999) Toxicology, 132(1), 1-8.

[31]Wu A. and Liu Y. (1999) Brain Res., 850(1), 249-252.

[32]Li T., Shi N., Xu H., Wei H., Wu Y., Zhou L. and Dong J. (2002) Chinese Journal of Industrial Hygiene and Occupational Diseases, 20(6), 427-429.

[33]Slaninova A., Smutna M., Modra H. and Svobodova Z. (2009) Neuro. Endocrinol. Lett., 30(1), 2-12.

[34]Dubey N., Raina R. and Khan A. (2012) Fluoride, 45(3), 242246.

[35]Zhang H., Li F.L., Cheng C., Liu B.D. and Cheng L.G. (2013) Pakistan J. Zool., 45(2), 511-519.

[36]Wilde D. (2006) Animal Reproduction Science, 96, 240-249.

[37]El- Zayat L., Baraldo L. and Etchenique R. (2005) Imaging in Neur. and Development: A Laboratory Manual, 391-394.

[38]Oyewopo A.O., Saalu L.C., Osinubi A.A., Imosemi I.O., Omotoso G.O. and Adefolaju G.A. (2010) J. Med. and Mesical. Sci., 1(5), 178-184.

[39]Babaei H., Azari O., Kheirandish R., Abshenas J. and Mohammadi N. (2010) Iran J. Vet. Surg., 5, 77-88.

[40]Ebisch I.M.W., Thomas C.M.G., Peters W.H.M., Braat D.D.M. and Steegers-Theunissen R.P.M. (2007) Human Reproduction Update, 13(2), 163-174.

[41]Bhalla P., Chadha V.D., Dhar R. and Dhawan D.K. (2007) Cellular and Molecular Neurobiology, 27(5), 595-607.

[42]Amara S., Abdelmelek H., Garrel C., Guiraud P., Douki T., Ravanat J. and Ben Rhouma K. (2008) Journal of Reproduction and Development, 54(2), 129-134. 
[43]Song Y., Leonard S.W., Traber M.G. and Ho E. (2009) The Journal of Nutrition, 139(9), 1626-1631.

[44]Maret W. (2000) J. Nutr., 130, 1455S-1458S.

[45]Zago M.P. and Oteiza P.I. (2001) Free Radic. Biol. Med., 31, 266-274.

[46]Koprucu S.S., Yonar E. and Seker E. (2008) Bull Environ. Contam Toxicol., 81, 253-257.

[47]Ozkan $O$ and Ustuner O. (2011) Kafkas Univ. Vet. Fak. Derg., 18(1), 69-74.

[48]Chargui I., Grissa I., Bensassi F., Hrira M.Y., Haouem S., Haouas Z. and Bencheikh H. (2012) A Molecular Assessment Biomed. Environ. Sci., 25(6), 672-683.

[49]McKinnon P.J. and Caldecott K.W. (2007) Ann. Rev. Genomics Hum. Genet., 8, 37-55.

[50]Yao K.W. and WANG J.D. (2008) Nat. J. Androl., 14, 268-271.

[51]Rashid A., Asmatullah N.Z. and Ara C. (2012) Pakistan J. Zool., 44(5), 1349-1353.

[52]Ismail M.F. and Mohamed H.M. (2012) Food Chem. Toxicol., 50, 3421-3425.

[53]Wu A., Hu Q. and Liu Y. (2000) Neurosci. Lett., 284(1-2), $29-32$.

[54]Ishii N., Senoo-Matsuda N., Miyake K., Yasuda K., Ishii T., Hartman P.S. and Furukawa S. (2004) Mech. Ageing. Dev., 125, 4146.

[55]Lau A.T.Y., Wang Y. and Chiu J.F. (2008) J. Cell. Biochemy., 104, 657-667.

[56]Gupta S.C., Mishra M., Sharma A., Deepak Balaji T.G.R., Kumar R., Mishra R.K. and Chowdhuri D.K. (2010) Ecotoxicology and Environmental Safety, 73(6), 1415-1423.

[57]Ho E. and Ames B.N. (2002) Cell Biol., 99, 16770-16775.

[58]Sliwinski T., Czechowska A., Kolodziejczak M., Jajte J., Jarosinska W.M. and Blasiak J. (2009) Cell Biology International, 33, $542 \mathrm{e} 547$.

[59]Perry D.K., Smyth M.J., Stennicke H.R., Salvesen G.S., Duriez P., Poirier G.G. and Hannun Y. (1997) Journal of Biological Chemistry, 272(30), 18530-18533. 